\title{
THE ROLE OF MULTISLICE SPIRAL CT IN CASES OF HEAD TRAUMA
}

\author{
Daisy Gupta1, Bharat Gupta², Sohan Singh ${ }^{3}$
}

${ }^{1}$ Senior Resident, Department of Radiodiagnosis, Government Medical College and Hospital, Amritsar. 2Junior Resident, Department of Radiodiagnosis, Government Medical College and Hospital, Amritsar. 3 Professor and HOD, Department of Radiodiagnosis, Government Medical College and Hospital, Amritsar.

\section{ABSTRACT}

Traumatic Brain Injury (TBI) continues to be an enormous public health problem even with modern medicine in the 21 st century. Traumatic Brain Injury (TBI) is a common and potentially devastating clinical problem. Proper management of TBI sequelae can significantly alter the clinical course especially within $48 \mathrm{hrs}$. of the injury. Neuroimaging techniques have become an important part of the diagnostic workup of such patients. In the acute setting, these imaging studies can determine the presence and extent of injury and guide surgical planning and minimally invasive interventions. Neuroimaging also can be important in the chronic therapy of TBI, identifying chronic sequelae, determining prognosis, and guiding rehabilitation. CT advantages for evaluation of the head-injured patient include its sensitivity for demonstrating mass effect, ventricular size and configuration, bone injuries, and acute haemorrhage. CT offers widespread availability, rapidity of scanning, and compatibility with medical devices.

\section{KEYWORDS}

TBI (Traumatic Brain Injury), CT, Head Trauma.

HOW TO CITE THIS ARTICLE: Gupta D, Gupta B, Singh S. The role of multislice spiral ct in cases of head trauma. J. Evolution Med. Dent. Sci. 016;5(70):5105-5111, DOI: 10.14260/jemds/2016/1158

\section{INTRODUCTION}

Traumatic Brain Injury (TBI) continues to be an enormous public health problem even with modern medicine in the 21st century. Most patients with TBI (75-80\%) have mild head injuries and almost $100 \%$ of persons with severe head injury and as many as two thirds of those with moderate head injury will be permanently disabled in some fashion and will not return to their premorbid level of function. The impact is even greater when one considers that most severe head injuries occur in adolescents and young adults. While various mechanisms may cause TBI, the most common causes include motor vehicle accidents, falls, assaults, sports-related injuries, and penetrating trauma. The male-to-female ratio for TBI is nearly 2:1 and TBI is much more common in persons younger than 35 years. ${ }^{1}$

\section{Pathoanatomic Classification}

A pathoanatomic classification describes the location or anatomical features of the abnormality to be targeted by a treatment and generally falls into the scheme of "where and what" terminology.

1. Scalp includes laceration, abrasion, oedema, ecchymoses, and subgaleal haematoma.

2. Skull fracture.

3. Extra-axial lesions like EDH, SDH, and SAH.

4. Intra-axial lesions like contusions, ICH, IVH, DAI (focal and diffuse) etc.

Each of these entities can be further described by their extent, location, multiplicity, and distribution.

Financial or Other, Competing Interest: None.

Submission 08-03-2016, Peer Review 18-05-2016,

Acceptance 23-05-2016, Published 01-09-2016.

Corresponding Author:

Dr. Bharat Gupta,

Room No. 77, F-Block,

Boys Hostel Medical College Campus,

Circular Road,

Amritsar-143001

Punjab.

E-mail: bharat3009@hotmail.com

DOI: $10.14260 /$ jemds/2016/1158
A number of classification schemes of these entities have been used for pathoanatomic description in many acute head injury studies including the Marshall score for CT findings.

\section{Marshall CT Classification of Head Injury.2}

\begin{tabular}{|c|c|}
\hline $\begin{array}{l}\text { Diffuse Injury I } \\
\text { (No visible } \\
\text { pathology) }\end{array}$ & $\begin{array}{l}\text { No visible intracranial pathology seen on } \\
\text { CT scan }\end{array}$ \\
\hline Diffuse Injury II & $\begin{array}{l}\text { Cisterns are present with midline shift } 0-5 \\
\mathrm{~mm} \text { and/or lesion densities present, no } \\
\text { high or mixed density lesion }>25 \mathrm{cc} \text { may } \\
\text { include bone fragments and foreign bodies }\end{array}$ \\
\hline $\begin{array}{l}\text { Diffuse Injury III } \\
\text { (Swelling) }\end{array}$ & $\begin{array}{c}\text { Cisterns compressed or absent with } \\
\text { midline shift } 0-5 \mathrm{~mm} \text {, no high or mixed } \\
\text { density lesion }>25 \mathrm{cc}\end{array}$ \\
\hline $\begin{array}{c}\text { Diffuse Injury IV } \\
\text { (Shift) }\end{array}$ & $\begin{array}{c}\text { Midline shift }>5 \mathrm{~mm} \text {, no high or mixed } \\
\text { density lesion }>25 \mathrm{cc}\end{array}$ \\
\hline $\begin{array}{l}\text { Evacuated mass } \\
\text { lesion }\end{array}$ & Any lesion surgically evacuated \\
\hline $\begin{array}{l}\text { Non-evacuated } \\
\text { mass }\end{array}$ & $\begin{array}{c}\text { High or mixed density lesion }>25 \mathrm{cc} \text {, not } \\
\text { surgically evacuated lesion }\end{array}$ \\
\hline
\end{tabular}

\section{TBI CLASSIFICATION \\ PATHOPHYSIOLOGICAL) ${ }^{3}$}

(PATHOANATOMIC

AND

\section{Primary Traumatic Lesions}

a. Primary Neuronal Injuries;-Cortical contusions, Diffuse axonal injury, Subcortical grey matter injury, Primary brainstem injury (DAI, direct laceration, pontomedullary tears).

b. Primary Haemorrhage; -Subdural haematoma, Epidural haematoma (Arterial, venous), Intracerebral haematoma, Diffuse haemorrhage (IVH, subarachnoid).

c. Primary Vascular Injuries; -Carotid-cavernous fistula, Arterial pseudoaneurysm, Arterial dissection/ laceration/occlusion, Dural sinus laceration/occlusion.

d. Traumatic Pia-Arachnoid Injuries; -Posttraumatic arachnoid cyst, Subdural hygroma.

e. Cranial Nerve Injuries. 


\section{Secondary Traumatic Lesions}

Major territorial arterial infarctions, Boundary and terminal zone infarctions, Diffuse hypoxic injury, Diffuse brain swelling/oedema, Pressure necrosis (Due to displacement and herniation), Secondary "delayed" haemorrhage, Secondary brainstem injury (mechanical compression, infarction, etc.) Others (Fat embolism, infection, etc.).

\section{IMAGING TECHNIQUES}

\section{Skull Radiographs. ${ }^{1,4}$}

Once an important part of the head injury evaluation, skull radiographs have been replaced by CT scans and are rarely used in patients with closed head injury. Skull x-rays are poor predictors of intracranial pathology and should not be performed to evaluate adult TBI. Lack of abnormality on skull films do not exclude major intracranial injury. Patients who are at high risk for acute intracranial injury must be imaged by CT. The scout view that is obtained with all CT exams can be used as "pseudo-skull film." Skull radiographs are occasionally used in the evaluation of penetrating head trauma to help provide a rapid assessment of the degree of foreign body penetration to screen for retained intracranial bullet fragments.

\section{CT Scan.1,4}

A CT scan is the diagnostic study of choice in the evaluation of TBI because it has a rapid acquisition time, is universally available, is easy to interpret, and is reliable. The standard CT scan for the evaluation of acute head injury is a noncontrast scan that spans from the base of the occiput to the top of the vertex in 5-mm increments. Three data sets are obtained from the primary scan, as follows: (1) bone windows, (2) tissue windows, and (3) subdural windows. These different types of exposure are necessary because of the significant difference in exposure necessary to visualise various intracranial structures. The bone windows allow for a detailed survey of the bony anatomy of the skull and the tissue windows allow for a detailed survey of the brain and its contents. The subdural windows provide better visualisation of intracranial haemorrhage especially those haemorrhages adjacent to the brain (e.g., subdural haematomas).

Advantages and Disadvantages of CT Scanning in the Head Trauma Evaluation. ${ }^{4}$

\begin{tabular}{|c|c|}
\hline Advantages & Disadvantages \\
\hline $\begin{array}{c}\text { Non-invasive and } \\
\text { rapid }\end{array}$ & $\begin{array}{c}\text { Traumatic vascular lesions maybe } \\
\text { missed. }\end{array}$ \\
\hline $\begin{array}{l}\text { Very sensitive for } \\
\text { acute haemorrhage }\end{array}$ & DAI is likely to be missed. \\
\hline $\begin{array}{c}\text { Defines nature of } \\
\text { ICH (i.e., } \mathrm{SDH}^{+}, \mathrm{SAH}^{\ddagger} \text { ) }\end{array}$ & Motion artefact may limit study. \\
\hline $\begin{array}{l}\text { Defines anatomical } \\
\text { location of lesion }\end{array}$ & $\begin{array}{l}\text { Posterior fossa lesions are poorly } \\
\text { depicted. }\end{array}$ \\
\hline $\begin{array}{l}\text { Identifies fractures } \\
\text { of the cranium }\end{array}$ & $\begin{array}{l}\text { Depressed skull fractures at the } \\
\text { vertex (or along the plane of an } \\
\text { axial scan) are poorly depicted. }\end{array}$ \\
\hline $\begin{array}{c}\text { Sensitive to } \\
\text { detecting } \\
\text { intracranial air }\end{array}$ & $\begin{array}{c}\text { The scanner has a weight limit and } \\
\text { a patient maybe too heavy. }\end{array}$ \\
\hline $\begin{array}{c}\text { Sensitive in } \\
\text { identifying foreign } \\
\text { objects }\end{array}$ & $\begin{array}{l}\text { A patient may decompensate } \\
\text { while in the scanner. }\end{array}$ \\
\hline
\end{tabular}

*Intracranial Haemorrhage; †Subdural Haemorrhage; ‡Subarachnoid haemorrhage.
MRI ${ }^{1,5,6}$

MRI has a limited role in the evaluation of acute head injury. Although, MRI provides extraordinary anatomic detail, it is not commonly used to evaluate acute head injuries because of its long acquisition times and the difficulty in obtaining MRIs in persons who are critically ill. However, MRI is used in the subacute setting to evaluate patients with unexplained neurologic deficits. MRI is superior to CT scan for helping identify Diffuse Axonal Injury (DAI) and small intraparenchymal contusions.

\section{MATERIALS AND METHODS}

The present study was conducted in Department of Radiodiagnosis and Imaging, Government Medical College, Amritsar, as 400 patients presenting with head trauma selected at random from emergency departments of Guru Nanak Dev Hospital and Shri Guru Teg Bahadur Hospital of Government Medical College, Amritsar, undergone CT scan of head in department. CT scans, a systematic approach and same protocol was used each time. Bone windows were examined for fractures beginning with the cranial vault and then examining the skull base and the facial bones. Soft tissue windows were examined for the presence of (1) extra-axial haematomas (e.g., epidural haematomas, subdural haematomas), (2) intraparenchymal haematomas, or (3) contusions. Next, the brain was surveyed for any evidence of pneumocephalus, hydrocephalus, cerebral oedema, midline shift, or compression of the subarachnoid cisterns at the base of the brain. Finally, the subdural windows were examined for any haemorrhage that which may not have been visualised on the soft tissue windows.

\section{OBSERVATIONS}

The epidemiological characteristics of the study population are showed in the following table.

\begin{tabular}{|c|c|c|}
\hline Age Groups (yrs.) & No. of Cases & $\%$ age \\
\hline $0-10$ & 43 & 10.8 \\
\hline $11-20$ & 57 & 14.3 \\
\hline $21-30$ & 116 & 29 \\
\hline $31-40$ & 77 & 19.3 \\
\hline $41-50$ & 51 & 12.8 \\
\hline $51-60$ & 36 & 9.0 \\
\hline$>60$ & 20 & 5.0 \\
\hline Total & 400 & 100 \\
\hline \multicolumn{3}{|c|}{ Table I: Age-Wise Distribution of Cases } \\
\hline
\end{tabular}

The distribution of the Pattern of Lesions on CT scan are as follows

\begin{tabular}{|c|c|c|}
\hline Type of Lesion & No. & $\mathbf{9}$ \\
\hline Total No. of Cases: & $\mathbf{4 0 0}$ & $\mathbf{1 0 0}$ \\
\hline $\begin{array}{c}\text { Total no of cases with no lesion-fracture } \\
\text { or intracranial: }\end{array}$ & 65 & 1.63 \\
\hline 1. Total no cases with scalp injury: & 290 & 72.5 \\
\hline 2. Total no of cases with fractures: & 232 & 58 \\
\hline 3. Total cases with hemosinus & 42 & $10.5 \%$ \\
\hline $\begin{array}{l}\text { 4. Total cases with opacified mastoid air } \\
\text { cells }\end{array}$ & 15 & $3.75 \%$ \\
\hline $\begin{array}{l}\text { 5. Total no of cases with } \\
\text { pneumocephalus }\end{array}$ & 40 & 10 \\
\hline $\begin{array}{l}\text { 6. Total number of primary intracranial } \\
\text { lesions (intra-axial and extra-axial) }\end{array}$ & 157 & \\
\hline
\end{tabular}




\begin{tabular}{|l|c|c|}
\hline a. Total no of EDH & 46 & 11.5 \\
\hline b. Total no of SDH & 22 & 5.5 \\
\hline c. Total no of SAH & 40 & 10 \\
\hline d. Total no of haemorrhagic contusions & 76 & 19 \\
\hline $\begin{array}{l}\text { e. Total no of non-haemorrhagic } \\
\text { contusions }\end{array}$ & 8 & 2 \\
\hline f. Total no of IVH & 12 & 3 \\
\hline $\begin{array}{l}\text { g. Total no of cases with } \\
\text { bleeding/effacement of cisterns }\end{array}$ & 18 & 4.5 \\
\hline $\begin{array}{l}\text { h. Total no of cases with bleed in } \\
\text { IHF/tentorium }\end{array}$ & 18 & 4.5 \\
\hline 7. Distribution of secondary lesions & 64 & 16 \\
\hline a. Total no of cases with oedema & 64 & 6 \\
\hline b. Total no of cases showing midline shift & 24 & 3 \\
\hline c. Total no of herniations & 12 & 3 Presenting with Head Trauma \\
\hline \multicolumn{3}{|c|}{$\begin{array}{l}\text { Table II: Distribution of Various Lesion (Extra and } \\
\text { Intracranial) Detected by CT Examination of Patients }\end{array}$} \\
\hline \multicolumn{3}{|c|}{} \\
\hline
\end{tabular}

\begin{tabular}{|c|c|c|c|c|c|}
\hline $\begin{array}{c}\text { Site of } \\
\text { Fracture }\end{array}$ & No. & $\%$ & $\begin{array}{c}\text { Site of } \\
\text { Fracture }\end{array}$ & No. & $\%$ \\
\hline 1. Frontal & 78 & 19.6 & Maxilla & 26 & 6.5 \\
\hline 2. Parietal & 88 & 22.1 & Zygomatic & 38 & 9.5 \\
\hline 3. Occipital & 37 & 9.3 & Sphenoid & 7 & 1.75 \\
\hline \multicolumn{3}{|c|}{ Temporal } & Nasal & 27 & 6.75 \\
\hline - Squamous & 63 & 15.8 & Ethmoid & 11 & 2.75 \\
\hline - $\quad$ Petrous & 64 & 16.1 & Pterygoid & 5 & 1.25 \\
\hline - Combined: & 32 & 8.0 & Mandible & 2 & 0.5 \\
\hline $\begin{array}{lr}\text { Orbit: } & \text { (One } \\
\text { blow } & \text { out } \\
\text { fracture) } & \end{array}$ & 49 & 12.25 & $\begin{array}{l}\text { Other sites } \\
\text { include } \\
\text { middle } \\
\text { cranial } \\
\text { fossa, sella, } \\
\text { etc. }\end{array}$ & 2 & 0.5 \\
\hline & & & $\begin{array}{l}\text { Cases of Fro } \\
\text { o Site }\end{array}$ & & \\
\hline
\end{tabular}

\begin{tabular}{|c|c|c|c|c|}
\hline $\begin{array}{c}\text { Type of } \\
\text { Lesion }\end{array}$ & No. & $\begin{array}{c}\text { \% of } \\
\text { Fractures }\end{array}$ & $\begin{array}{c}\text { P } \\
\text { value }\end{array}$ & Significance \\
\hline EDH & 42 & $18.10 \%$ & $\begin{array}{c}0.000 \\
\left(\mathrm{x}^{2}=23,\right. \\
\mathrm{df}=1)\end{array}$ & $\begin{array}{c}\text { Highly } \\
\text { significant }\end{array}$ \\
\hline SDH & 18 & $7.75 \%$ & $\begin{array}{c}0.02 \\
\left(\mathrm{x}^{2}=5.4,\right. \\
\mathrm{df}=1)\end{array}$ & $\begin{array}{c}\text { Significant at } \\
5 \% \\
\text { significance } \\
\text { level }\end{array}$ \\
\hline SAH & 33 & 14.2 & $\begin{array}{c}0.001 \\
\left(\mathrm{x}^{2}=10.9,\right. \\
\mathrm{df}=1)\end{array}$ & $\begin{array}{c}\text { Significant at } \\
1 \% \\
\text { significance } \\
\text { level }\end{array}$ \\
\hline $\begin{array}{c}\text { Cistern (bleed/ } \\
\text { effacement) }\end{array}$ & 15 & 6.4 & $\begin{array}{c}0.02 \\
\left(\mathrm{x}^{2}=4.9,\right. \\
\mathrm{df}=1)\end{array}$ & $\begin{array}{c}\text { Significant at } \\
5 \% \\
\text { significance } \\
\text { level }\end{array}$ \\
\hline $\begin{array}{c}\text { Bleed in IHF/ } \\
\text { tentorium }\end{array}$ & 12 & 5.1 & $\begin{array}{c}0.4 \\
\mathrm{x}^{2}=0.58, \\
\mathrm{df}=1)\end{array}$ & $\begin{array}{c}\text { Not } \\
\text { significant }\end{array}$ \\
\hline $\begin{array}{c}\text { Haemorrhagic } \\
\text { contusions }\end{array}$ & 68 & $29.3 \%$ & $\begin{array}{c}0.000 \\
\left(\mathrm{x}^{2}=38.1,\right. \\
\mathrm{df}=1)\end{array}$ & $\begin{array}{c}\text { Highly } \\
\text { significant }\end{array}$ \\
\hline $\begin{array}{c}\text { Non- } \\
\text { haemorrhagic } \\
\text { contusions }\end{array}$ & 5 & $2.1 \%$ & $\begin{array}{c}0.7\left(\mathrm{x}^{2}=.06,\right. \\
\mathrm{df}=1)\end{array}$ & $\begin{array}{c}\text { Not } \\
\text { significant }\end{array}$ \\
\hline
\end{tabular}

\begin{tabular}{|c|c|c|c|c|}
\hline $\begin{array}{c}\text { Intraventricular } \\
\text { haemorrhage }\end{array}$ & 10 & $4.3 \%$ & $\begin{array}{c}0.071 \\
\left(\mathrm{x}^{2}=3.2,\right. \\
\mathrm{df}=1)\end{array}$ & $\begin{array}{c}\text { Not } \\
\text { significant }\end{array}$ \\
\hline $\begin{array}{c}\text { Pneumocep- } \\
\text { halus }\end{array}$ & 40 & $17.2 \%$ & $\begin{array}{c}0.000 \\
\left(\mathrm{x}^{2}=32.1,\right. \\
\mathrm{df}=1)\end{array}$ & $\begin{array}{c}\text { Highly } \\
\text { significant }\end{array}$ \\
\hline Oedema & 51 & $21.9 \%$ & $\begin{array}{c}0.000 \\
\mathrm{x}^{2}=14.7, \\
\mathrm{df}=1)\end{array}$ & $\begin{array}{c}\text { Highly } \\
\text { significant }\end{array}$ \\
\hline Midline shift & 21 & $9.0 \%$ & $\begin{array}{c}0.003 \\
\left(\mathrm{x}^{2}=9.1,\right. \\
\mathrm{df}=1)\end{array}$ & $\begin{array}{c}\text { At } 1 \% \\
\text { significance } \\
\text { level }\end{array}$ \\
\hline Herniations & 12 & $5.1 \%$ & $\begin{array}{c}0.4\left(\mathrm{x}^{2}=4.4,\right. \\
\mathrm{df}=1)\end{array}$ & $\begin{array}{c}\text { Not } \\
\text { significant }\end{array}$ \\
\hline \multicolumn{5}{|c|}{ Table IV: Fractures with Extra- and Intra-axial Lesions } \\
with Secondary Changes
\end{tabular}

\section{RESULTS}

Three hundred thirty two patients (83\%) were males and 68 patients (17\%) were female. (Sex ratio $\mathrm{M}: \mathrm{F}=4.9: 1$ ). Age ranged from 8 months to 85 years with mean age $32.06 \pm 17.7$ years. The highest frequency of head trauma occurred series i.e. 116 (29\%) cases were in the age group of 21-30 years followed by 77 (19.3\%) cases in age group 31-40 years.

Of 400 patients of head trauma studied using CT scans, scalp injury is the most common finding 290 cases followed by fractures (232) accounting for 58\% cases. The most common site of fracture was parietal followed by frontal. Fractures included facial fractures, skull base fractures, vault of skull, both linear and depressed ones. Other CT finding associated with fracture are EDH in $91 \%$ cases, SDH in $81.8 \%$, contusions in $89.4 \%$, oedema in $79.6 \%$, SAH in $82.5 \%$, pneumocephalus in $40(10 \%)$ cases, intraventricular haemorrhage in 12 , bleeding in cisterns in 6 while effacement of cistern in 12 cases. CT grading according to Marshall's classification, $60 \%$ patients belong to grade I, 33.3\% are grade II, 2.3 and 3.8 belong respectively to grade III and IV. 15 patients have NEML (Nonevacuated mass lesion).

\section{DISCUSSION}

Head injury is a major health problem and a frequent cause of death and disability. In developing countries, the incidence of traumatic brain injury is increasing as traffic increases besides other confounding factors such as industrialisation, falls, and ballistic trauma. ${ }^{[7,8]}$ Radiographic examination of the skull is an essential part of management of head trauma,[9] but its limitations in plain radiographs are now recognised even in diagnosis of skull fractures.[10] CT facilitates a comprehensive diagnosis and permits early and targeted intervention.

In our study, we found that the mean age of our patients is $32 \pm 17$ year's age with maximum number of patients in the age group of 21-30 years (116-29\%) followed by 31-40 years age group with 77 (19.3\%) patients. In our series, males were more prevalent than women with head injury. The male:female ratio is $4.9: 1$ with $83 \%$ males to $17 \%$ females. Bordignon et al and Lee et al confirmed the similar findings. This is the age group, which is the most active group with maximum number of vehicles being driven by them and also prone to rash driving particularly under the influence of alcohol and drugs. 


\section{SCALP INJURY}

Total no of cases with scalp injury are 290 (72.5\%). Scalp injury is associated with underlying fracture is seen in 191 out of 290 cases (65\%). Ghebrehiwet et al found soft tissue swelling associated with fractures in $2.7 \%$ of cases. Bordignan et al found fractures in $14.3 \%$ cases with soft tissue swelling. ${ }^{11,12}$

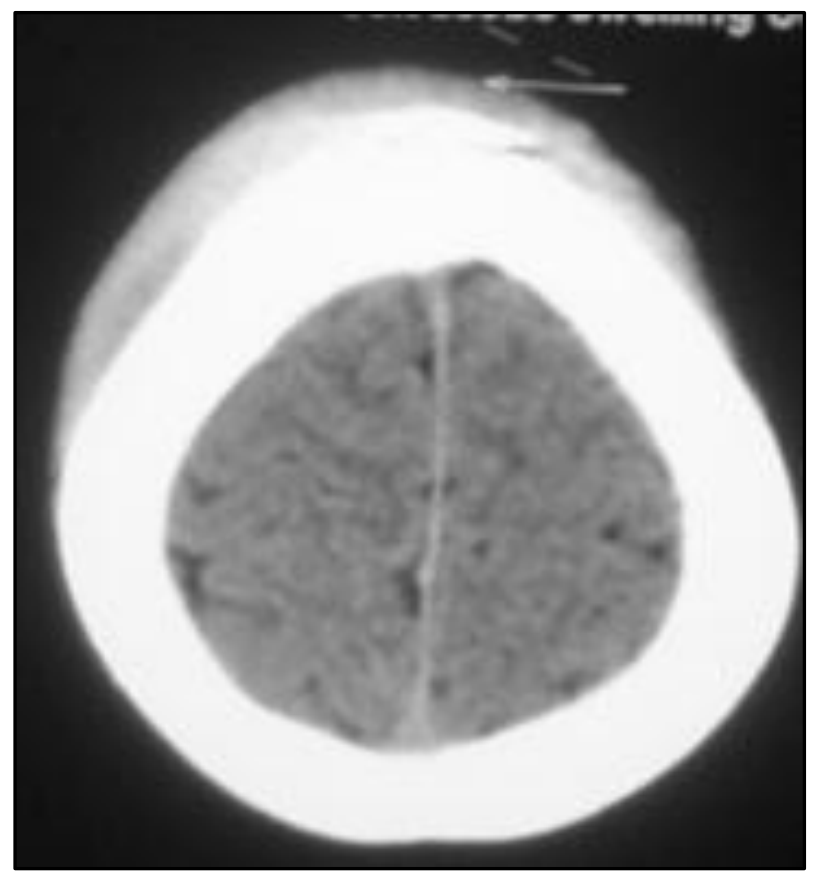

Fig. 1: CT Axial Image showing Soft Tissue Swelling

\section{FRACTURES}

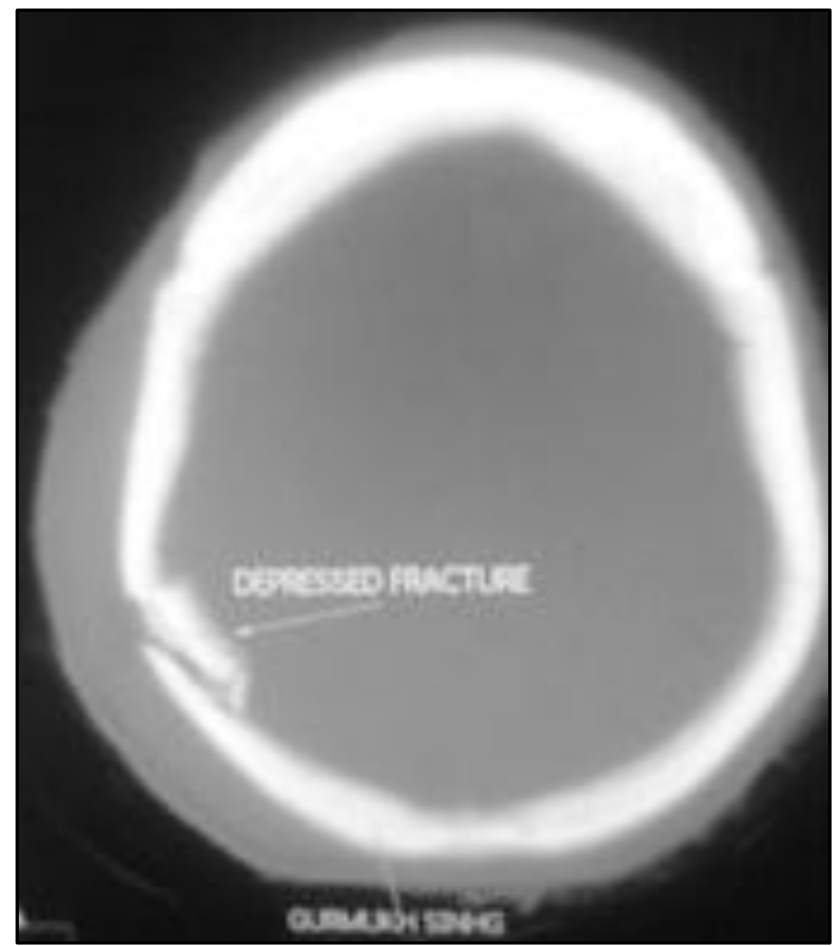

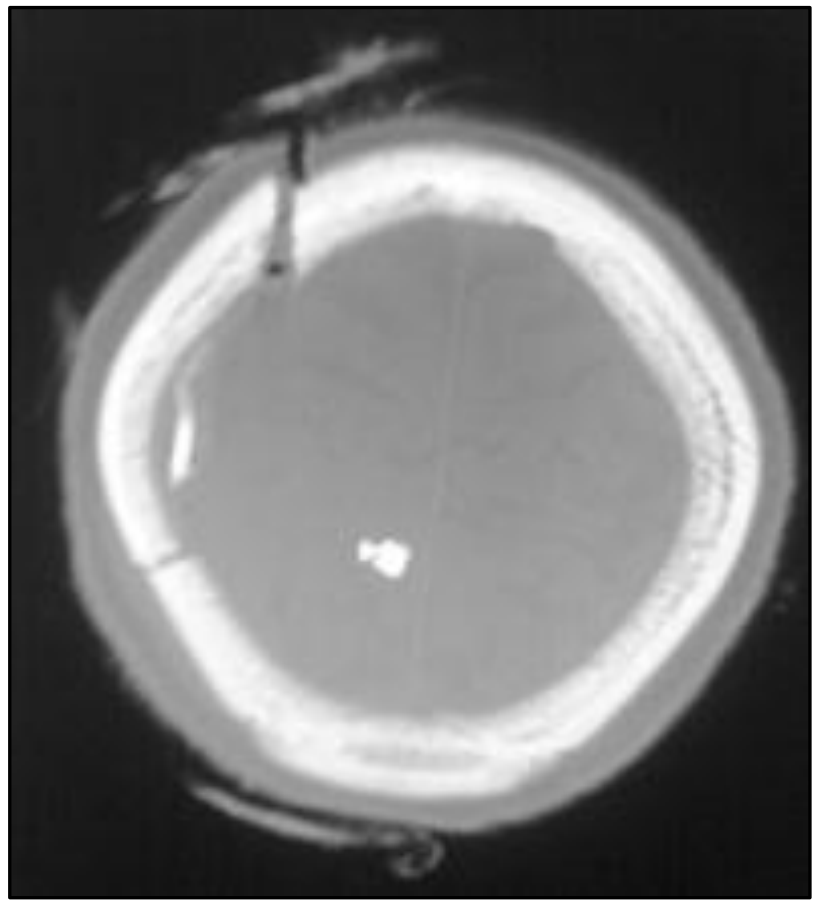

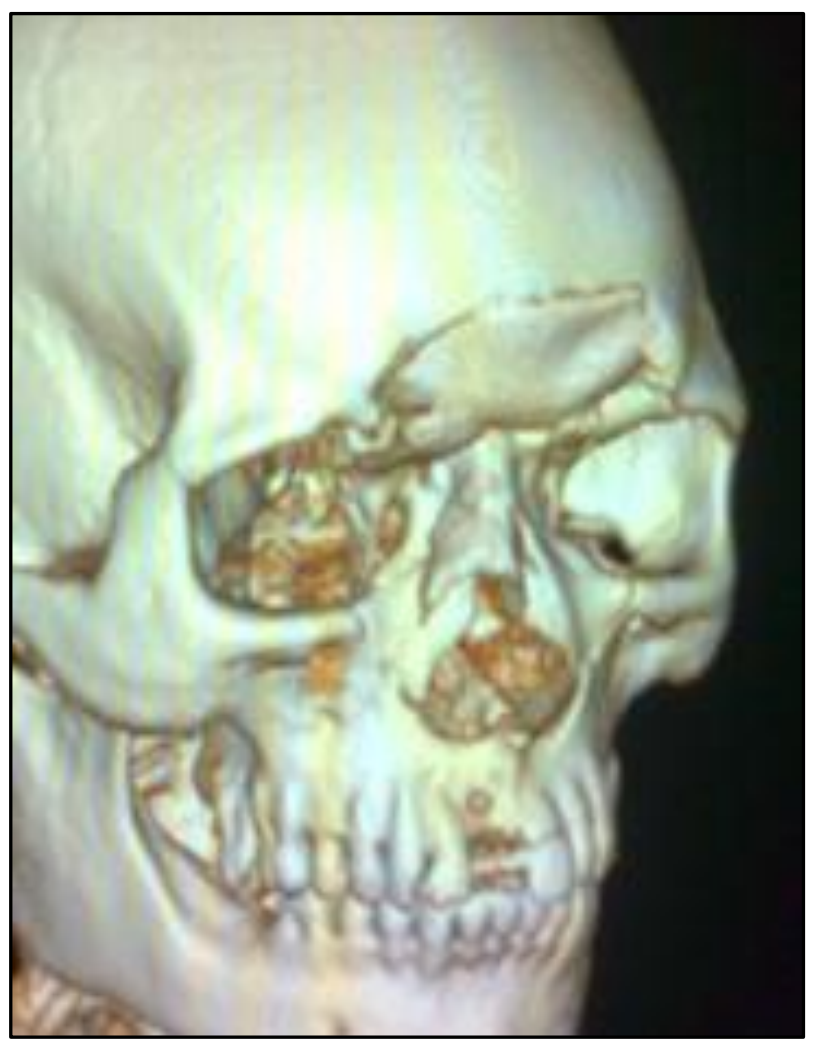

Fig. 2: CT Axial and 3D Reformatted Image showing Fractures

Fractures are seen in 232 patients amounting to $58 \%$ of cases in our series. Nagy et al found incidence of fractures in abnormal cases to be $30.7 \% .^{13}$ The most common site is parietal $(22.1 \%)$ followed by frontal bones $(19.6 \%)$. The fractures are usually involving multiple bones in contiguous location particularly the facial bones. 
Relation of Various Intracranial Lesions with Presence of Fractures and types of Fracture

In our study, total number of patients with fractures are 232 (58\%) with intracranial lesions seen in 129 cases with fractures (55.6\%). 168 cases had no fracture, 28 (16.6\%) patients had intracranial lesions in such cases. Macpherson et al found in their study that out of 850 patients of fractures, intracranial haematoma was seen in $71 \%$ of cases. Intracranial lesions are seen without fractures in $46 \%$. In a study by Lee et al out of $158(18 \%)$ fractures, intracranial lesions were found in $138(87 \%)$ cases. $166(22 \%)$ cases of intracranial lesions were seen in cases without fracture (740-82\%). Our study shows EDH is associated with fractures in $91.3 \%$ of cases compared to $87 \%$ found by Macpherson et al ${ }^{14}$ and $83.3 \%$ by Stein et al. SDH is associated with fractures in $81.8 \%$ in our study while Macpherson gave the incidence as $72 \%$ and Stein et al as $50 \%$. Contusions are seen in association with fractures in $89.4 \%$ cases in our study. Macpherson calculated the association as $77 \%$ and Stein et al $45.07 \%$. Zimmerman et al found fractures in $75 \%$ cases of contusions. Our study has found higher incidence of oedema (79.68\%) and SAH (82.5\%) in relation to fractures as compared to Stein et al who found the incidence to be $39 \%$ and $20 \%$, respectively. Our study correlates well with the study done by Macpherson et al and Zimmerman et al.14,15

\section{PNEUMOCEPHALUS}

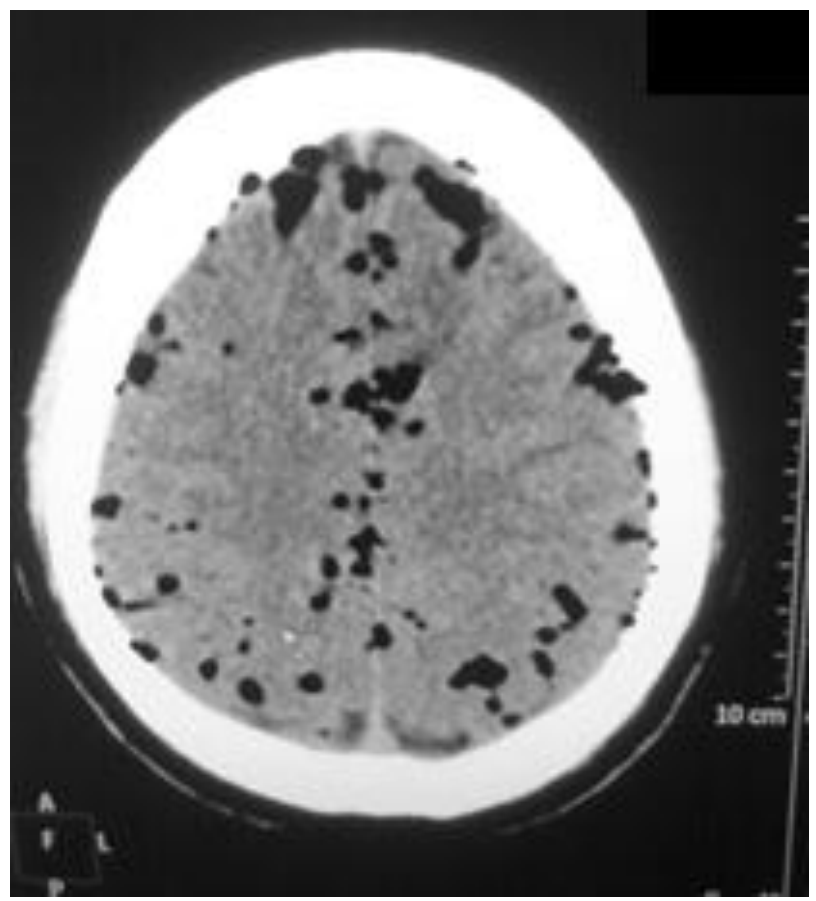

Fig. 3: CT Axial Image showing Extensive Pneumocephalus with Underlying Fracture

Pneumocephalus is seen in $40(10 \%)$ of total cases. Fractures are seen in all the cases of aerocele. Nagy et $\mathrm{al}^{13}$ found pneumocephalus in $2.6 \%$ cases in their series while Bordignon et $\mathrm{al}^{11}$ and Lee et al ${ }^{12}$ detected it in approximately $1.6 \%$ cases.

\section{Intracranial Lesions}

Total no of patients with intracranial lesions are 157 (39.25\%) with total of 278 lesions including EDH, SDH, SAH, Contusions- haemorrhagic and non-haemorrhagic, IVH, oedema, bleeding in cisterns and IHF/tentorium. Ghebrehiwet et al found the incidence as $17.2 \%$ in their study, $33.9 \%$ by Lee et al, $7.6 \%$ by Smits et al, $58.3 \%$ by Zimmerman et al. Stein et al calculated the incidence to be $17.2 \%{ }^{16}$ and Nagy et al as $3.3 \%$. Variability of the incidence in work done by different authors is due the selection of patients, according to the clinical severity of the cases or random sampling or consecutive selection irrespective of clinical status. The incidence of intracranial lesions varies from $3.3 \%$ to $58.3 \%$ in various studies. Our study has incidence of $41 \%$, which falls within this range.

\section{EXTRADURAL HAEMATOMA}

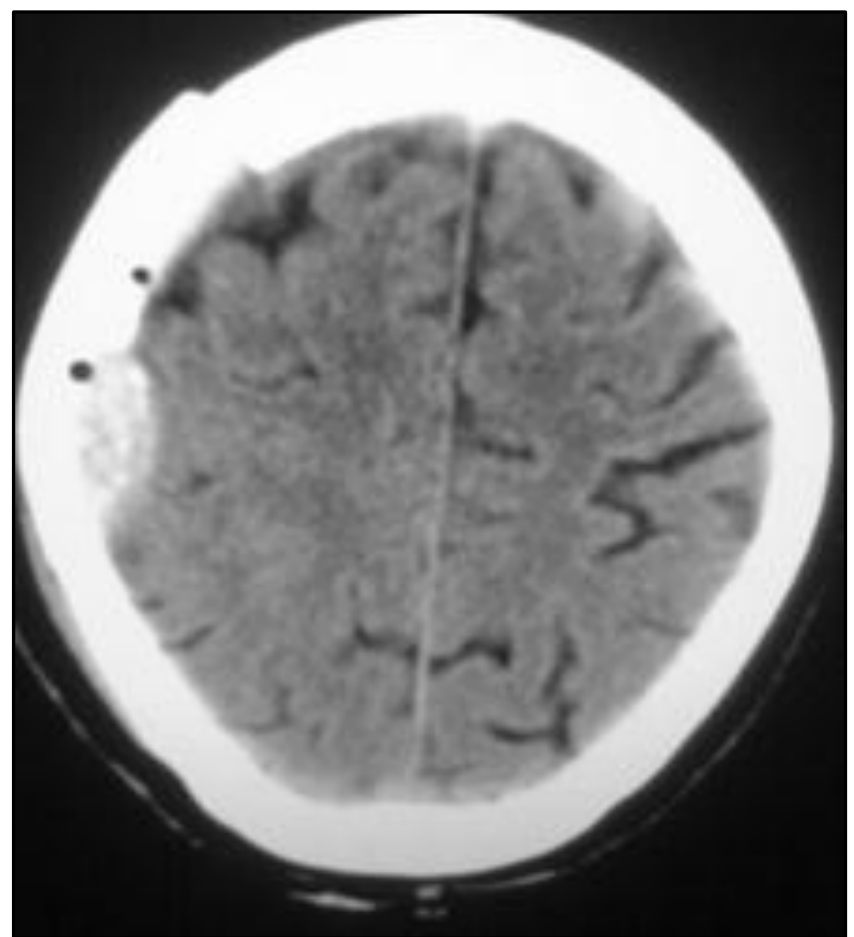

Fig. 4: CT Axial Image showing EDH Underlying the Fracture with Air Pockets

In our study, EDH was found in 46 cases i.e. $11.5 \%$ of total patients. Bordignon et al ${ }^{11}$ found EDH in $1.4 \%$ cases, $3.6 \%$ cases by Ghebrehiwet et al $8,3.2 \%$ by Lee et al, $\underline{12} 14 \%$ by Smits et $\mathrm{al}, 164.9 \%$ by Zimmerman et $\mathrm{al}^{5}$. These studies vary in incidence of EDH from $1.4 \%$ to $14 \%$ by various authors. The most common site of EDH in our study is temporal and frontal. In a study by Toyama et al, 8 the most common site is temporal, frontal followed by occipital region. In our study, also found that EDH is associated with fractures in 42 out of 46 cases accounting for $91.3 \%$ cases. Toyama et $\mathrm{al}^{17}$ and Osborn et $\mathrm{al}^{18}$ found the similar observations. In our study, we found EDH significantly caused oedema and midline shift with associated mass effects in some cases. This is again in concordance with study done by Zimmerman et al. ${ }^{5}$

\section{Subdural Haematoma}

In our study, SDH was seen in 22 cases accounting for $5.5 \%$ of total patients SDH is found in $6.4 \%$ cases by Bordignon et al, 11 $12.7 \%$ of cases by Ghebrehiwet, et al, $89.6 \%$ by Lee et al, 12 28\% by Smits et al, $1612.5 \%$ cases by Zimmerman et al. ${ }^{5}$ Yamaura et $\mathrm{al}^{6}$ found the incidence of SDH varying between $0.8 \%$ in mild head injury cases to $23 \%$ cases in severe head injury cases. The 
most common site in our cases is fronto-temporo-parietal region.

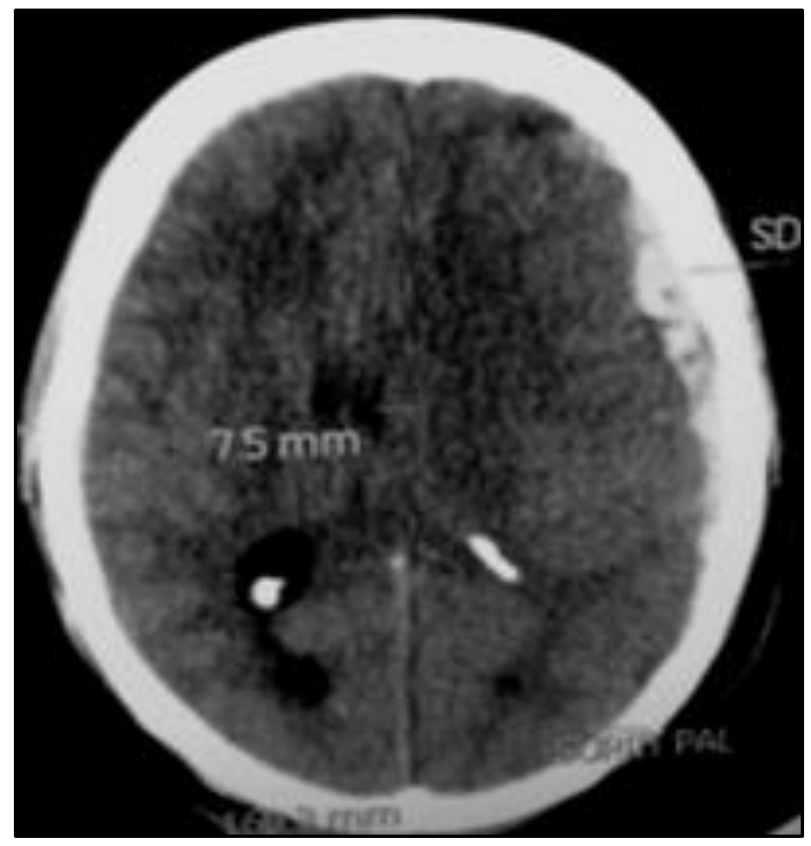

Fig. 5: CT Axial Image showing Small SDH in Left Frontoparietal Convexity with Oedema with Compression of Ipsilateral Ventricles with $7.5 \mathrm{~mm}$ Midline Shift

\section{SUBARACHNOID HAEMORRHAGE}

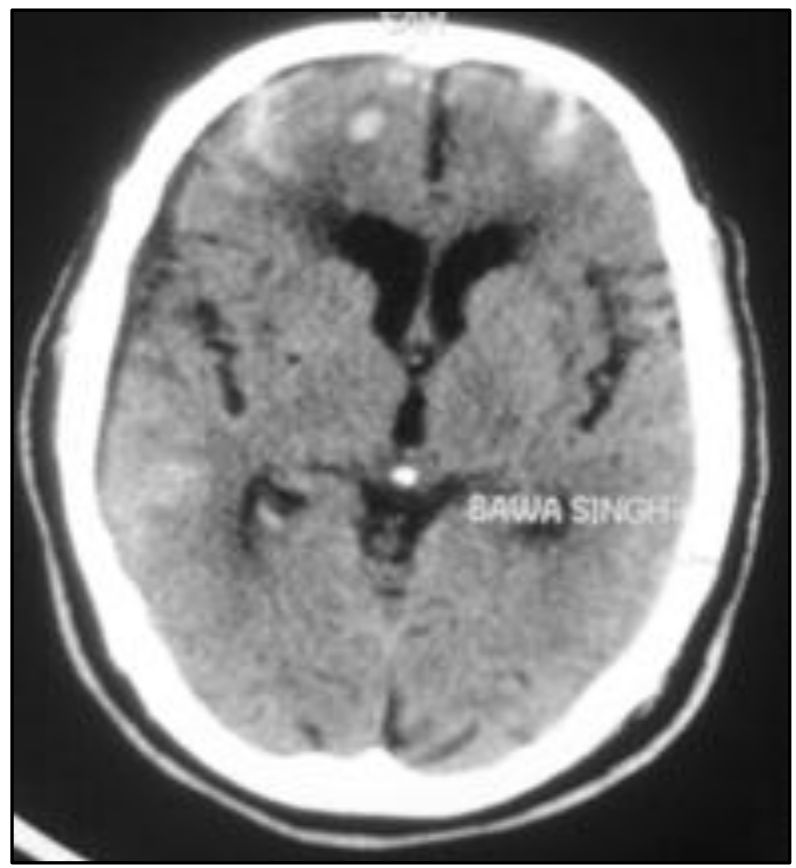

Fig. 6: CT Axial Image showing SAH Frontoparietal Sulci with Haemorrhagic Contusion-Frontal Lobe

In our study, $\mathrm{SAH}$ is seen in 40 cases accounting for $10 \%$ of total cases, $25.4 \%$ of cases with intracranial lesions. Bordignon et al ${ }^{11}$ found $\mathrm{SAH}$ in $6.6 \%$ cases, $1.8 \%$ of cases were seen by Ghebrehiwet et al, ${ }^{8} 2.8 \%$ by Lee et al, 12 35\% by Smits et al. ${ }^{16}$ Eisenberg et al found incidence of SAH in 39\% of severely injured cases. The most common site is frontal followed by parietal and sylvian fissures. Toyama et $\mathrm{al}^{17}$ found SAH most frequent over convexities followed by fissures and basal cisterns.

\section{CONTUSIONS}

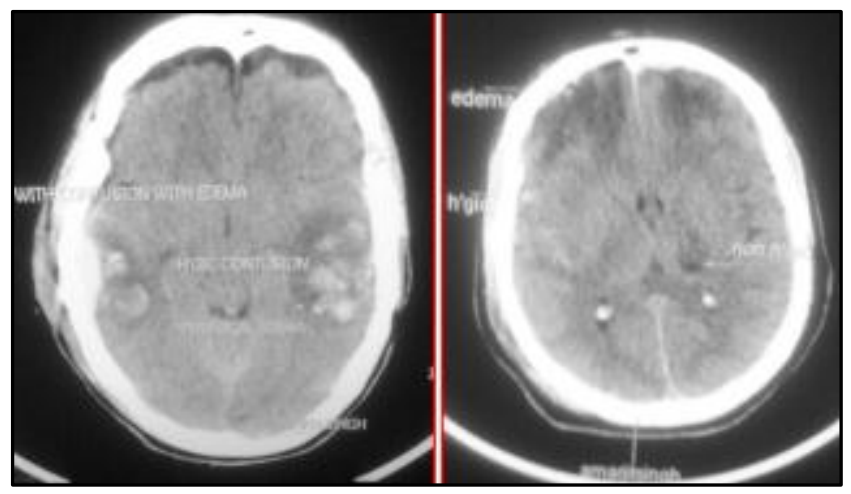

Fig. 7: CT Axial One Images showing B/I Multiple Haemorrhagic Contusions another Image showing NonHaemorrhagic Contusions

In our study, contusions is seen in 76 cases accounting for $19 \%$ of total cases, $48.4 \%$ of cases with intracranial lesions. Bordignon et al ${ }^{11}$ found contusions in $12.9 \%$ of their cases, $16.4 \%$ of cases by Ghebrehiwet et al, ${ }^{2} 13.6 \%$ by Lee et al, 12 $49 \%$ by Smits et al, $1621.3 \%$ cases by Zimmerman et al. 5 The most common site is frontal followed by temporal.

In our study, $42 \%$ of cases are multiple and $17 \%$ are bilateral. Toyama et al ${ }^{6}$ has found multiple contusions in $30 \%$ cases whereas Zimmerman et $\mathrm{al}^{5}$ found multiple contusions in $29 \%$ cases.

\section{Intraventricular Haemorrhage}

In our study, we found that IVH is seen in 12 (3\%) cases out of $6 \%$ of intracranial lesions and Ghebrehiwet et al ${ }^{8}$ found IVH in $9.1 \%$ of cases of intracranial haematoma, $1.8 \%$ of total cases, whereas Yamaura et al ${ }^{6}$ found IVH in $7.4 \%$ of cases in severely head injured group. Yamaura et al ${ }^{10}$ found haemorrhagic contusions in 7 out of 8 cases of IVH. In our study, haemorrhagic contusions are seen in 8 out of 12 cases of IVH.

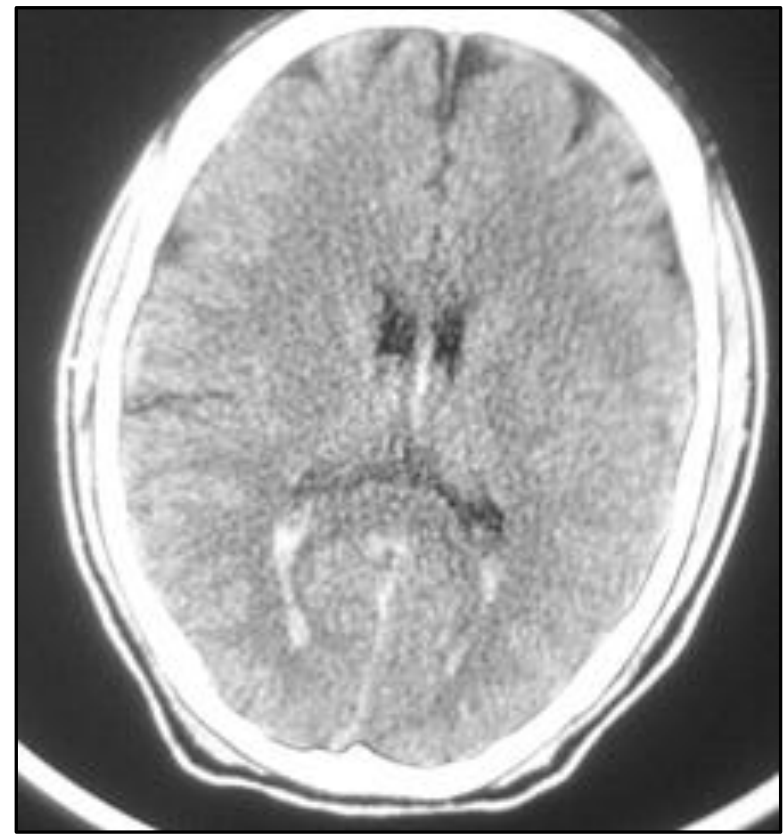

Fig. 8: CT Axial Image showing Intraventricular Haemorrhage 


\section{OEDEMA}

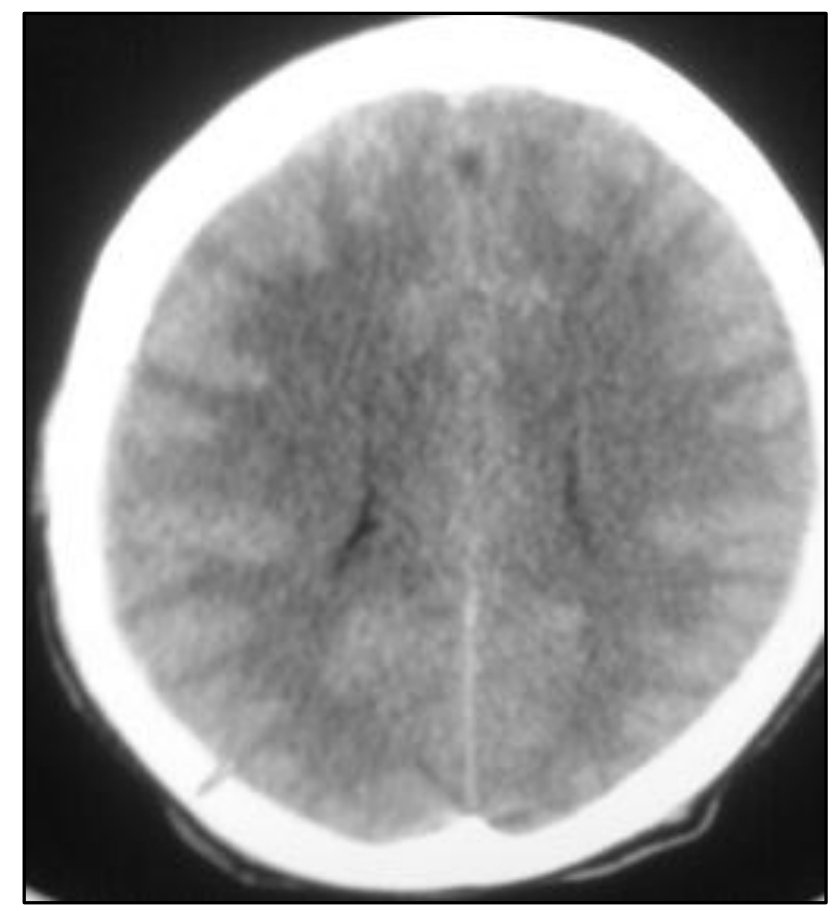

Fig. 9: CT Axial Images showing Cerebral Oedema with Obliteration of Sulci and Gyri and Compression of Ventricles

In our study, cerebral oedema is seen in 64 cases accounting for $16 \%$ of total cases and $40.76 \%$ of total cases with intracranial lesions. Bordignon et al ${ }^{11}$ found oedema in $7.5 \%$ cases, Nagy et al ${ }^{13}$ in $2.6 \%$ cases, Zimmerman et al ${ }^{5}$ in $16.1 \%$ cases. Stein et al 15 found oedema in $5.3 \%$ of total cases and $30.9 \%$ of cases with intracranial lesions. Our study has 17 cases of oedema with midline shift forming $26.5 \%$ of cases of oedema. Eisenberg et al ${ }^{17}$ found oedema without midline shift in $39 \%$ cases and with midline shift in $16 \%$ of total cases.

\section{CONCLUSION}

CT scans is helpful in assessing the degree of intracranial injury in predicting outcome and if findings are normal in avoiding unnecessary hospitalisation. It is very sensitive to acute haemorrhage or skull fractures and aids in evaluating intracranial haemorrhage, skull fractures, mass effect and midline shift, obliteration of the basal cisterns, and evidence of herniation (subfalcine, tonsillar, or uncal).

\section{REFERENCES}

1. David Crippen. Head trauma:

http://emedicine.medscape.com/article/433855.

Update 19 April, 2010.
2. Marshall LF, Marshall SB, Klauber MR, et al. A new classification of head injury based on computerised tomography. Journal of Neurosurgery 1991;75(1):S1420.

3. Gentry LR. Imaging of closed head injury. Radiology 1994;191(1):1-17.

4. Leonardo Rangel-Castilla. Closed head trauma: http://emedicine.medscape.com/article/251834. Update Sept 22, 2009.

5. Zimmerman RA, Bilanuik LT, Gennarelli T, et al. Cranial computed tomography in diagnosis and management of acute head trauma. Am J Roentgenol 1978;131(1):27-34.

6. Toyama Y, Kobayashi T, Nishiyama Y, et al. CT for acute stage of closed head injury. Radiation Medicine 2005;23(5):309-16.

7. Emejulu JK, Ekweogwu C, Nottidge T. The burden of motorcycle-related neurotrauma in South-East Nigeria. J Clin Med Res 2009;1(1):13-7.

8. Ghebrehiwet M, Quan LH, Andebirhan T. The profile of CT scan findings in acute head trauma in Orrota Hospital, Asmara, Eritrea. Journal of Eritrean Medical Association 2009;4(1):5-8.

9. Ohaegbulam SC. The role of emergency radiographic examination of the skull in trauma. Ghana Med J 1977; 16:255-7.

10. Nakahara K, Shimizu S, Utsuki S, et al. Linear fractures occult on skull radiographs: a pitfall at radiological screening for mild head injury. J Trauma 2011;70(1): 180-2.

11. Bordignon KC, Arruda WO. CT scan findings in mild head trauma: a series of 2000 patients. Arq Neuro Psiquiatr 2002;60(2-A):204-10.

12. Lee YB, Kwon SJ. A more detailed classification of mild head injury in adults and treatment guidelines. J Korean Neurosurg Soc 2009;46(5):451-8.

13. Nagy KK, Joseph KT, Krosner SM, et al. The utility of head computed tomography after minimal head injury. Journal Trauma 1999;46(2):268-70.

14. Macpherson B, Macpherson P, Jennett B. CT evidence of intracranial contusion and haematoma in relation to presence, site, and type of skull fracture. Clinical Radiology 1990;42(5):321-6.

15. Stein SC, Ross SE. Mild head injury: a plea for routine early CT scanning. Journal Trauma 1992;33(1):11-3.

16. Smits M, Dippel DWJ, Steyerberg EW, et al. Predicting intracranial traumatic findings on computed tomography in patients with minor head injury: the chip prediction rule. Annals of Internal Medicine 2007;146(6):397-405.

17. Eisenberg HM, Gary HE, Aldrich EF, et al. Initial CT findings in 753 patients with severe head injury a report from the NIH traumatic coma data bank. J Neurosurg 1990;73(5):688-98. 